\title{
Plant traits and environment: floating leaf blade production and turnover of waterlilies
}

Peter F. Klok ${ }^{1,2}$ ， Gerard van der Velde ${ }^{\text {Corresp. 1,3 }}$

${ }^{1}$ Department of Animal Ecology and Physiology, Institute for Water and Wetland Research, Radboud University Nijmegen, Nijmegen, Netherlands

2 Department of Particle Physics, Institute for Mathematics, Astrophysics and Particle Physics, Radboud University Nijmegen, Nijmegen, Netherlands

3 Naturalis Biodiversity Center, Leiden, Netherlands

Corresponding Author: Gerard van der Velde

Email address: g.vandervelde@science.ru.nl

Floating leaf blades of waterlilies fulfill several functions in wetland ecosystems by production, decomposition and turnover as well as exchange processes. Production and turnover rates of floating leaf blades of three waterlily species, Nuphar lutea (L.) Sm., Nymphaea alba L. and Nymphaea candida Presl, were studied in three fresh water bodies, differing in trophic status, $\mathrm{pH}$ and alkalinity. Length and percentages of leaf loss of marked leaf blades were measured weekly during the growing season. Area and biomass were calculated based on leaf length and were used to calculate the turnover rate of floating leaf blades. Seasonal changes in floating leaf production showed that values decreased in the order: Nymphaea alba, Nuphar lutea, Nymphaea candida . The highest production was reached for Nuphar lutea and Nymphaea alba in alkaline, eutrophic water bodies. The production per leaf was relatively high for both species in the acid water body. Nymphaea candida showed a very short vegetation period and low turnover rates. The ratio Total potential leaf biomass/ Maximum potential leaf biomass $\left(P / B_{\max }\right.$ ) of the three species ranged from 1.35-2.25. The ratio Vegetation period (Period with floating leaves)/Mean leaf life span ranged from 2.94-4.63, the ratio Growth period (Period with appearance of new floating leaves)/Vegetation period from 0.53-0.73. The clear differences between Nymphaea candida versus Nuphar lutea and Nymphaea alba, may be due to adaptations of Nymphaea candida to an Euro-Siberic climate with short-lasting summer conditions. 


\section{7 (revision PEERJ)}

2 Plant traits and environment: floating leaf blade production and turnover of 3 waterlilies

5 Peter F. Klok · Gerard van der Velde

$7 \quad$ P. F. Klok $\cdot$ G. van der Velde $(\bowtie)$

8 Department of Animal Ecology and Physiology, Institute for Water and Wetland

9 Research, Radboud University Nijmegen, Heyendaalseweg 135, 6525 AJ Nijmegen, The

10 Netherlands

11 e-mail: g.vandervelde@science.ru.nl

13 P. F. Klok

14 Department of Particle Physics, Institute for Mathematics, Astrophysics and Particle 15 Physics, Radboud University Nijmegen, Nijmegen, The Netherlands

17 G. van der Velde

18 Naturalis Biodiversity Center, Leiden, The Netherlands 


\section{Abstract}

23 Floating leaf blades of waterlilies fulfill several functions in wetland ecosystems by

24 production, decomposition and turnover as well as exchange processes. Production and

25 turnover rates of floating leaf blades of three waterlily species, Nuphar lutea (L.) Sm.,

26 Nymphaea alba L. and Nymphaea candida Presl, were studied in three fresh water bodies,

27 differing in trophic status, $\mathrm{pH}$ and alkalinity. Length and percentages of leaf loss of

28 marked leaf blades were measured weekly during the growing season. Area and biomass

29 were calculated based on leaf length and were used to calculate the turnover rate of

30 floating leaf blades.

31 Seasonal changes in floating leaf production showed that values decreased in the order:

32 Nymphaea alba, Nuphar lutea, Nymphaea candida. The highest production was reached

33 for Nuphar lutea and Nymphaea alba in alkaline, eutrophic water bodies. The production

34 per leaf was relatively high for both species in the acid water body. Nymphaea candida

35 showed a very short vegetation period and low turnover rates. The ratio Total potential

36 leaf biomass/ Maximum potential leaf biomass $\left(\mathrm{P} / \mathrm{B}_{\max }\right)$ of the three species ranged from

37 1.35-2.25. The ratio Vegetation period (Period with floating leaves)/Mean leaf life span

38 ranged from 2.94-4.63, the ratio Growth period (Period with appearance of new floating

39 leaves)/Vegetation period from 0.53-0.73. The clear differences between Nymphaea

40 candida versus Nuphar lutea and Nymphaea alba, may be due to adaptations of

41 Nymphaea candida to an Euro-Siberic climate with short-lasting summer conditions. 


\section{Introduction}

46 Aquatic macrophytes can be considered as the basic frame of wetland ecosystems, called 47 macrophyte-dominated systems (Den Hartog \& Van der Velde, 1988; Jeppesen, 48 Søndergaard \& Christoffersen, 1998). The nymphaeid macrophyte growth form has 49 mainly floating leaves, flowers on or elevated above the water surface and roots in the 50 sediment of shallow open waters or littoral borders (Luther, 1983; Van der Velde, 1981).

51 Waterlilies (Nymphaeaceae) as characteristic nymphaeids form the base of nymphaeid52 dominated systems (Van der Velde, 1980). In the littoral zonation waterlilies grow often 53 in between submerged macrophytes and helophytes, but the number of studies are few 54 compared to those of the latter two groups. However, in shallow freshwater lakes, 55 waterlilies can cover large areas (e.g. Brock, Van der Velde \& Van de Steeg, 1987; 56 Zbikowski, Kobak \& Zbikowska, 2010), where submerged plants disappeared by 57 accumulation of organic matter on the sediment during succession, eutrophication and 58 acidification (Arts et al., 1990; Wiik et al., 2015). Waterlilies are adapted to such 59 conditions (Dacey \& Klug, 1979; Dacey, 1980, 1981, Smits et al., 1990). Important

60 factors for functioning in the aquatic wetland ecosystem are patterns of floating leaf 61 production, decomposition and turnover. Leaves have a life history as their pattern of 62 behavior from development from a primordium on a meristem to death by senescence or 63 by environmental conditions which cause the dying off of the living tissue. During its 64 existence it changes from being an importer and consumer of resources to being an 65 exporter (Harper, 1977). The development and senescence of the leaves seem to be 66 controlled by the plant itself through hormonal control (Chabot \& Hicks, 1982). 
67 Floating leaf blades (laminae) are important for exchange processes such as

68 photosynthesis (Smits et al., 1988; Snir, Gurevitz \& Marcus, 2006), gas exchange (Dacey

69 \& Klug, 1979; Dacey, 1980, 1981; Ribaudo et al., 2012) and chemical accumulation e.g.

70 by hydropotes (Lavid et al., 2001; Javadi et al., 2010). They make a significant

71 contribution to the detritus food chain by decomposition (Brock, 1985; Brock, Boon \&

72 Paffen, 1985;Brock et al., 1985; Kok \& Van der Velde, 1991; Kok, 1993) and function

73 subsequently as food for detritivores (Kok et al., 1992). Floating leaf blades also have

74 other functions, viz. as substratum for organisms at and near the water surface (e.g. Van

75 der Velde, 1980; Hafner, Jasprica \& Caric, 2013), as isles in the open water for air-

76 breathing animals (e.g. Van der Velde \& Brock, 1980; Willmer, 1982; Van der Velde et

77 al., 1985), as substratum and nutrient for fungi (Vergeer \& Van der Velde, 1997;

78 Kowalik, 2012), as food for specialized invertebrate herbivores (Gaevskaya, 1969; Brock

79 \& Van der Velde, 1983; Van der Velde, Kok \& Van Vorstenbosch, 1989; Kok, Van der

80 Velde \& Landsbergen, 1990) and for vertebrates (Gaevskaya, 1969; Paillisson \& Marion, $812001)$

82 This study focuses on the floating leaf blade production of Nuphar lutea (L.) Sm.,

83 Nymphaea alba L. and Nymphaea candida Presl. Floating leaf blades are mentioned in

84 the paper further as leaves. The research questions for this basic study are: Are there

85 differences or similarities in production, turnover and other leaf characteristics between

86 these waterlily species and are these differences related to environmental conditions by

87 phenotypic plasticity or can they be considered biological species traits? For that purpose

88 these aspects were compared between two co-existing species per site and between the

89 same species in different sites. 
90

\section{Materials and Methods}

92

93 Sites

94

95 Field research took place in three fresh water bodies in The Netherlands: Haarsteegse

96 Wiel (HW), Oude Waal (OW) and Voorste Goorven (VG); dense nearly mono-specific

97 stands occurred at all three sites. Within those stands, plots of a fixed area of $1 \mathrm{~m}^{2}$ were 98 laid out: three for Nuphar lutea (HW and OW, 1977; VG, 1988), two for Nymphaea alba

99 (OW, 1977; VG, 1988) and one for Nymphaea candida (HW, 1977). The Haarsteegse

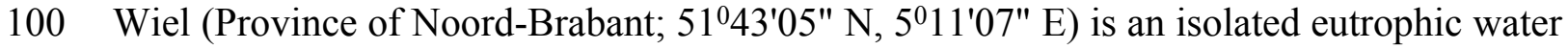

101 body with low alkalinity that consists of two connected breakthrough ponds created by

102 dike bursts along the River Meuse. During the summer period, in the deep lake 103 stratification occurs. The bottom of the nymphaeid stands consists of sand and a 104 sapropelium layer with increasing thickness towards the littoral border. The Oude Waal 105 (Province of Gelderland; 51051'13" N, 5053'35" E) is a highly eutrophic, alkaline oxbow

106 lake in the forelands of the River Waal. The depth during the growth season is shallow,

107 except for three remnants of former breakthrough ponds. The water level is dependent on 108 precipitation, upward seepage, overflow of the River Waal in winter and/or spring (which

109 strongly influences water chemistry and quality), and evaporation. The bottom consists of

110 clay and sand, covered by a sapropelium layer of varying thickness in the nymphaeid

111 beds. The Voorste Goorven (Province of Noord-Brabant; 51033'53" N, 5012'26" E) is a

112 shallow, oligotrophic, isolated, culturally acidified moorland pool, showing very low 
113 alkalinity values. The hydrology is mainly dependent on precipitation, upward seepage

114 and evaporation. The lake has a poorly buffered sandy soil. For further characteristics of

115 the investigated water bodies see Table 1. Chemical characteristics were derived from

116 Brock, Boon \& Paffen (1985) and Kok, Van der Velde \& Landsbergen (1990).

117

118 Solar radiation, air and water temperature

119

120 Daily measurements of solar radiation and air temperature collected by the Royal

121 Netherlands Meteorological Institute during the growing season (April-December) were

122 converted to 7-day moving averages, to eliminate large fluctuations on consecutive days.

123 Also decade-averaged values for the periods 1971-1980 and 1981-1990 were used to get

124 an impression of the "standard" yearly pattern for those periods. Water temperature data

125 were collected weekly in the plots by means of a mercury thermometer at a depth of $5 \mathrm{~cm}$

126 at HW and OW in 1977 as part of the standard data taking procedure.

127

128 Field data from the plots

129

130 To collect field data, six representive plots of $1 \mathrm{~m}^{2}$ were laid out in the centre of mono-

131 specific stands, surveying one rhizome apex per plot. A non-destructive leaf-marking

132 method was used to mark all floating leaves within a plot, which enabled data collection

133 during the complete life-span of the leaves. A square perforated PVC tube frame, held

134 approximately $15 \mathrm{~cm}$ below the water surface by cork floaters and anchored by four

135 bricks, bordered a plot (Fig. 1). In this way the unrolling of floating leaves in the plot was 
136 not hindered and all leaves having their petioles within the frame were counted and

137 measured. A leaf was considered still present as long as, after fragmentation, tissue of the

138 lamina was connected to the petiole in the case of OW and HW. In VG the leaf was

139 considered gone when it was completely decayed but not fragmented and sunk under the

140 water surface. The time that a leaf was present at the water surface was considered to be

141 the leaf life span. Terms used in other studies are leaf persistence (Brock et al., 1983) and

142 longevity (Chabot \& Hicks, 1982).

143 Measurements and observations of all leaves within a plot took place weekly during the

144 growing season. It included tagging newly unrolled leaves by numbered Rotex tapes fixed

145 around the petiole just under the leaf (insert Fig. 1), counting the actual number of leaves,

146 measuring leaf length in $\mathrm{mm}$ (from the leaf tip to a basal lobe tip) and visually estimating

147 leaf loss as percentage of the potential leaf area of each leaf. During the whole growing

148 season, undamaged leaves were harvested at random a few metres outside the plots at

149 each location to measure length $(\mathrm{mm})$, area $\left(\mathrm{cm}^{2}\right)$ and biomass (Ash-Free Dry Weight in

$150 \mathrm{mg}$ ). The vegetation period was calculated as the number of days beginning with leaf

151 emergence at the water surface within the plot and ending on the first day that no leaf was

152 observed any longer. The growth period was calculated as the number of days at which

153 new floating leaves appeared at the water surface.

154

155 Potential, actual and photosynthetic leaf area and leaf biomass

156

157 Since floating leaf loss occurs, even before a leaf unrolls, a distinction was made between

158 potential, actual and photosynthetic leaf area. The potential area was defined as the area 
159 of an entirely intact leaf. The actual area was defined as the potential area minus the area

160 that is missing (e.g. caused by fauna, dehydration of the leaf margin, mechanical damage,

161 absence of leaf parts due to decay). The photosynthetic area is defined as the actual area

162 minus yellow, brown or decayed areas, thus the green leaf area left. The same distinction

163 is made for leaf biomass.

164

165 Analysis of leaf length in time

166

167 Each leaf blade was measured weekly. To analyze the leaf length in time, both a linear

168 and a quadratic curve fitting model were applied to make general leaf length predictions

169 during the growing season per species per site:

$$
\begin{aligned}
& L_{1}^{\prime}(t)=a_{1}+b_{1} t \\
& L_{2}^{\prime}(t)=a_{2}+b_{2} t+c_{2} t^{2}
\end{aligned}
$$

172 where:

$$
L_{i}^{\prime}(t)=\text { predicted leaf length }(\mathrm{cm}) \text { at time } t
$$

$$
t \quad=\text { time (day) }
$$

$a_{i}, b_{i}, c_{i}=$ correlation coefficients

176 Corrected begin and end lengths of all leaves were used for the determination of the

177 correlation coefficients. Values were corrected to maximum lengths to reflect the

178 potential values. Curve fitting was performed separately on begin and end lengths, using

179 both the linear model, corresponding to a linear increase (equation (1)), and the quadratic

180 model, corresponding to a length optimum during the growing season (equation (2)). 
182 Correlation of leaf area and leaf biomass with leaf length

183

184 Potential area and biomass were calculated by correlation with the end leaf length, using 185 quadratic regression equations (Van der Velde \& Peelen-Bexkens, 1983). Biomass is 186 given in grams ash-free dry weight (AFDW). Field data from randomly harvested 187 undamaged, fully green leaves outside the plots were used to determine equation 188 coefficients. The equations were then applied to the field data from the plots.

189 Mathematically, the equations for potential area and biomass are described by:

$$
\begin{aligned}
& A_{i}(L)=c_{i} L^{2} \\
& B_{i, j}(L)=c_{i, j} L^{2}
\end{aligned}
$$

192 where:

$$
A_{i}(L)=\text { potential leaf area of species } i \text { at length } L\left(\mathrm{~cm}^{2}\right)
$$

$$
\begin{array}{ll}
B_{i, j}(L) & =\text { potential leaf biomass of species } i \text { in water body } j \text { at length } L(\mathrm{~g} \text { AFDW) } \\
L & =\text { leaf length }(\mathrm{cm}) \\
c_{i}, c_{i, j} & =\text { correlation coefficients } \\
i & =\text { species (Nuphar lutea, Nymphaea alba, Nymphaea candida) } \\
j & =\text { investigated water body (HW, OW, VG) }
\end{array}
$$

The total potential area (leaf area index) and biomass on each sampling date of species $i$ in plot $j$, are calculated by summation over the individual leaves:

$$
A_{t o t, t} \quad=c_{i} \Sigma L_{n, t}^{2}=\Sigma A_{i}(L)
$$

$$
B_{t o t, t}=c_{i, j} \Sigma L_{n, t}^{2}=\Sigma B_{i, j}(L)
$$

203 where:

$$
A_{\text {tot, } t}=\text { total potential leaf area at time } t\left(\mathrm{~cm}^{2}\right)
$$


205

206

207

208

209

210

211 The total annual production of potential area and biomass was calculated by summation,

212 using the maximum lengths of all produced leaves per species per plot for conversion to

213 biomass data with the aid of the regression equations between leaf length and biomass

214 based on the leaves collected outside the plot. Actual and photosynthetic area and

215 biomass were calculated from the potential area and biomass by subtracting the field data

216 loss percentages per leaf per species per plot.

218 Turnover rates and other ratios

219

220 Ratios give information on the regulation of the floating leaf production by the plant itself

221 irrespectable of or in response to environmental conditions and therefore can be 222 considered species traits (Kok, Van der Velde \& Landsbergen, 1990). The turnover rate 223 of leaves is calculated as the ratio Vegetation period/Mean leaf life span (Brock et al., 224 1983) and as the ratio Total potential biomass production/Maximum potential biomass $225\left(\mathrm{P} / \mathrm{B}_{\max }\right)$. Other ratios used are Mean leaf life span/Total number of leaves, Growth $226 \mathrm{period} /$ Vegetation period and the ratios Maximum leaf area/Total leaf area, Maximum 
227 leaf biomass/Total leaf biomass and Leaf area/Leaf biomass for the potential, actual and 228 photosynthetic maxima.

229

230 Statistics

231

232 The package R (R Core Team, 2015) was used for statistics. Mean values with standard 233 deviations have been computed for leaf life span, potential begin- and end leaf length, 234 potential leaf area and potential leaf biomass. Welch's t-test was used to test for 235 differences in leaf life span between species for all plots. Linear regression was used to 236 test for differences in potential begin and end leaf length between species for all plots.

\section{Results}

239

240 Solar radiation, air and water temperature

241

242 The 1977 and 1988 solar radiation and air temperature patterns were sinusoidal-shaped 243 curves with a yearly period (Fig. 2).

245 Number of leaves, leaf life span and vegetation period 246

247 Nymphaea alba showed the highest floating leaf production, followed by Nuphar lutea, 248 and Nymphaea candida. The production of the floating leaves is sequential without 249 cohorts. 
250 The curves of the cumulative total number of leaves show that leaf production stopped

251 after the beginning of September for Nuphar lutea and Nymphaea alba and in the first

252 half of August for Nymphaea candida (Fig. 3).

253 Maximum and mean leaf life span were highest for the Nuphar lutea and Nymphaea alba

254 in the oligotrophic and acid VG and for Nymphaea candida in the eutrophic and alkaline

255 HW (Table 2). Significant differences for the leaf life span were found between Nuphar

256 lutea in the eutrophic, alkaline OW and in oligotrophic, acid VG, between Nuphar lutea

257 in OW and Nymphaea alba in VG and between Nuphar lutea in OW and Nymphaea

258 candida in HW (Table 3).

259 Nymphaea candida clearly showed a short vegetation period, compared to Nuphar lutea 260 and Nymphaea alba. Nuphar lutea in HW showed the longest vegetation period.

261

262 Leaf length in time

263

264 During the whole growing season, Nuphar lutea developed the longest leaves. The mean 265 begin and end lengths of leaves of Nuphar lutea were relatively short in the oligotrophic, 266 acid VG and for Nymphaea candida in the eutrophic, alkaline HW (Table 2). The leaf 267 length highly varied for Nuphar lutea and Nymphaea alba in the eutrophic, alkaline OW 268 (Fig. 4).

269 The mean begin and end lengths were high for Nuphar lutea in HW and OW, compared 270 to Nymphaea candida in HW and Nuphar lutea and Nymphaea alba in VG. The mean

271 leaf length growth was highest for Nymphaea alba in OW (Table 2). 
272 The results of the analysis of the leaf length time patterns show better fits for the

273 quadratic model (equation (2)) compared to the linear model (equation (1)), indicating an

274 optimum in leaf length during the growing season (Table 4). The quadratic fit of Nuphar

275 lutea in VG for only 22 end lengths, has a low correlation with no significance. High

276 correlation and low significance levels are shown for Nymphaea alba (OW and VG, both

277 begin and end lengths) and for Nymphaea candida (HW, begin length) and high

278 correlation with higher significance are shown for Nuphar lutea (HW, OW, VG, both

279 begin and end lengths, except VG end length). If the c-coefficient value of the quadratic

280 equation is very low, the curve turns into a straight line. In this case the correlation

281 constants and the significance values do not differ much, indicating that both the

282 quadratic and the linear model can be used. This applies both to the all observed values

283 dataset of Nuphar lutea (HW, end length) and to the end values dataset of Nuphar lutea

284 (HW and OW), showing a tendency towards increasing leaf lengths during the growing

285 season instead of the occurrence of an optimum.

286 For the potential begin leaf length, all plot data were significantly different with the 287 exception of Nuphar lutea in the eutrophic, alkaline HW versus Nuphar lutea in the 288 eutrophic, alkaline OW ( $\mathrm{p}=0.5763)$, Nymphaea alba in OW versus Nuphar lutea in 289 oligotrophic, acid VG $(\mathrm{p}=0.3040)$, and Nymphaea candida in HW versus Nymphaea 290 alba in $\mathrm{VG}(\mathrm{p}=0.5400)$.

291 This was also found for the potential end leaf length with the exception of Nuphar lutea 292 in HW versus Nuphar lutea in OW ( $\mathrm{p}=0.3200)$, Nymphaea alba in OW versus Nuphar 293 lutea in VG ( $\mathrm{p}=0.9151$, and Nymphaea candida in HW versus Nymphaea alba in VG ( $\mathrm{p}$ $294=0.6704)$ and idem for potential leaf area $(p=0.1687,0.0290,0.0893$, resp. $)$. 
Length-area and length-biomass relations

297

298 Regression equations for the computation of leaf area and leaf biomass from end leaf

299 length are shown in Tables 5 and 6. The ratio length/area ranged from high to low in the

300 order Nymphaea alba, Nymphaea candida and Nuphar lutea. The ratio length/biomass

301 ranged from high to low in the order Nymphaea alba, Nuphar lutea and Nymphaea 302 candida.

303

304 Leaf area and leaf biomass

305

306 The potential maxima were reached when relatively many large leaves were present. The

307 dates of these maxima differed from the dates of the actual and photosynthetic maxima 308 for Nuphar lutea and Nymphaea candida in the eutrophic, alkaline HW, and for

309 Nymphaea alba in the oligotrophic, acid VG. Both mean potential leaf area and mean

310 potential biomass (per day and per leaf) were low for the VG plots, as well as for

311 Nymphaea candida, with the exception of the mean potential biomasses per leaf in VG,

312 which were relatively high. So, although the total biomass production in VG was low, the

313 mean production per leaf was relatively high. For Nymphaea candida the ratios of the

314 maximum of potential, actual, photosynthetic and total potential for both leaf area and

315 biomass clearly showed high values because of lower leaf loss (Table 7).

316 Seasonal patterns of potential, actual and photosynthetic area and biomass show a rapid

317 and steady decline in floating blade area for Nuphar lutea in the eutrophic, alkaline HW 
318 and for Nuphar lutea and Nymphaea alba in the eutrophic, alkaline OW, in contrast to

319 minimal decline for Nymphaea candida in HW and Nuphar lutea and Nymphaea alba in

320 the oligotrophic, acid VG. The leaf area and biomass patterns also showed differences

321 between species and location. Nuphar lutea showed highest values in the eutrophic,

322 alkaline HW, intermediate values in the eutrophic, alkaline OW and lowest values in the

323 oligotrophic, acid VG. Similarly, Nymphaea alba showed higher values in OW and lower

324 in VG. In HW the Nuphar lutea values were higher than for Nymphaea candida. In OW,

325 as well as in VG, the Nymphaea alba values were higher than the Nuphar lutea values

326 (Fig. 5).

327 The potential biomass in nearly all plots appeared to be significantly different with the

328 exception of Nuphar lutea in OW versus Nymphaea alba in VG $(\mathrm{p}=0.2197)$.

329

330 Turnover rates and other ratios

331

332 The ratio Total/Maximum number of leaves was approximately constant for Nymphaea

333 alba and Nuphar lutea, but was much lower for Nymphaea candida (Table 7).

334 The turnover rate Vegetation period/Mean leaf life span was high for Nuphar lutea in

335 both eutrophic and alkaline HW and OW and Nymphaea alba in OW, lower for Nuphar

336 lutea and Nymphaea alba in oligotrophic, acid VG and lowest for Nymphaea candida in

337 HW (Table 7). The turnover rate $\mathrm{P} / \mathrm{B}_{\max }$ showed similar values for Nuphar lutea and

338 Nymphaea alba and a clearly lower value for Nymphaea candida. The other ratios

339 showed similar trends. The ratio Mean leaf life span/Total leaf production however 
340 showed the highest value for Nuphar lutea in VG followed by Nymphaea candida in HW,

341 and much lower values in the other plot (Table 7).

342 LAI (leaf area index or maximum potential leaf area) ranged in our study from 0.39-2.79

$343 \mathrm{~m}^{2} \cdot \mathrm{m}^{-2}$ (Table 2).

344

345 Discussion

346

347 The 1977 and 1988 solar radiation and air temperature patterns were in good agreement

348 with the decade-averaged values from the Royal Netherlands Meteorological Institute

349 (http://www.knmi.nl/climatology/daily_data/selection.cgi and

350 http://www.knmi.nl/index_en.html, both accessed June 22, 2014), indicating that 1977

351 and 1988 can be considered "normal" years. The radiation curves showed an optimum in

352 June and the temperature curves showed an optimum in July-August, indicating a lag

353 period of at least a month. After their optima, the radiation decrease was faster than the

354 temperature decrease. Similar patterns were described by Howard-Williams (1978),

355 Jacobs (1979) and Nienhuis \& De Bree (1980). The water temperature was closely related

356 to the air temperature, especially in the shallow OW and VG. The water temperature

357 pattern in HW showed smaller fluctuations, due to the greater depth with, consequently, a

358 more stable temperature balance. Besides, after the summer optima of radiation and

359 temperature had passed, the water in HW stayed longer at higher temperature levels

360 compared to OW and VG.

361 The curves reflecting the actual number of leaves show maxima around August,

362 corresponding to the maxima of the temperature curves and not to the June maxima of the 
363 radiation curves which show a gradual decrease afterwards. So water temperature seems

364 to be a limiting factor for leaf production and not radiation.

365 Acidity might be an important factor during leaf development. Lower $\mathrm{pH}$ values of VG

366 influence the ratio between total and maximum number of leaves to higher values for

367 Nymphaea alba and Nuphar lutea, compared to HW and OW. However, also wind and

368 wave action (low for HW) and trophic status (eutrophic, alkaline for HW, highly

369 eutrophic and alkaline for OW and oligotrophic, acid for VG), might be relevant factors.

370 The mean leaf life span of Nuphar lutea and Nymphaea alba in the nutrient poor VG was

371 relatively long, which agrees with previous research (Brock, 1985). Differences in

372 maximum and mean leaf life span of species are quite small. The range of the mean

373 floating leaf life span in our study was 38-48 days. These values cannot be considered a

374 differentiating species trait. In the literature we found a mean floating leaf life span of 31

375 days for Nuphar advena in the USA (Twilley et al. 1985), 40 days for Nuphar japonica in

376 Japan (Aramaki, Tsuchiya \& Iwaki, 1989) and 21-55 days for Nymphaea tetragona

377 (Kunii \& Aramaki, 1992).

378 The vegetation period of Nymphaea candida is definitely shorter than the periods of

379 Nuphar lutea and Nymphaea alba, mainly because of a late start in June.

380 Low $\mathrm{pH}$ and oligotrophic environment of VG lead to low turnover rates compared to the

381 alkaline and nutrient richer environments of $\mathrm{HW}$ and $\mathrm{OW}$.

382 Leaf length appears to be influenced by the physico-chemical conditions in the case of

383 Nuphar lutea and Nymphaea alba. The mean begin and end lengths of leaves were

384 relatively short for the VG plots and for Nymphaea candida in HW. During the whole

385 growing season, Nuphar lutea developed the longest leaves. The leaf length highly varied 
386 for Nymphaea alba in OW and to a lesser extent for Nuphar lutea in VG. This high

387 variation can be attributed to the development of secondary rhizome short shoots that

388 develop leaves with small lengths.

389 Seasonal patterns of the actual, potential and photosynthetic area and biomass clearly

390 show a difference between initial decomposition in alkaline and acid waters: during most

391 of the growing season the relative actual and photosynthetic leaf area and biomass ratios

392 in the nutrient poor and acidified VG were stable in the range $100 \%-75 \%$ due to less leaf

393 loss, while in the alkaline and eutrophic HW and OW, a rapid and steady decline started

394 soon after leaf development. So the nutrient poor, acid conditions of VG prevent leaf loss

395 for Nuphar lutea and Nymphaea alba.

396 Leaf lengths and leaf growth in VG were relatively low for Nymphaea alba and Nuphar

397 lutea. However, leaves of both species in VG do have relatively high biomasses.

398 Evidently, low $\mathrm{pH}$ and low buffering capacity may lead to smaller leaves and relatively

399 high biomass values per leaf. The low length-biomass regression curve of OW indicates

400 relatively low leaf biomass values, compared to leaf area values. Hence, the Leaf

401 length/Leaf biomass ratio was affected by environmental conditions.

402 Statistics show a clear difference for leaf life span between the species in the acidic and

403 oligotrophic VG and Nuphar lutea in OW. Comparison of similar data (mean leaf life

404 span, turnover rates) of other research shows Nymphaea candida as deviating species

405 with respect to turnover rates.

406 Ribaudo et al. (2012) found LAI's of $1.05(0.17)$ and $1.19(0.19) \mathrm{m}^{2} \cdot \mathrm{m}^{-2}$ for Nuphar

407 lutea in N. Italy, Twilley et al. (1985) mentioned a LAI of $0.82 \mathrm{~m}^{2} \cdot \mathrm{m}^{-2}$ for Nuphar 
408 advena, and Aramaki, Tsuchiya \& Iwaki (1989) $1.5 \mathrm{~m}^{2} . \mathrm{m}^{-2}$ for Nuphar japonica which

409 all fall within the range found in the present study.

410 The very low LAI and leaf production of Nuphar lutea in VG may be due to a lack of

411 nutrients, in particular phosphate. This species occurs normally in eutrophic water with

412 phosphate concentrations in water and interstitial water higher than for Nymphaea alba

413 (Van der Velde, Custers \& De Lyon, 1986). Hutchinson (1975) found that the floating

414 leaves of Nymphaea odorata contain less phosphorus than those of Nuphar advena when

415 they occur sympatric in the same water bodies, which may be due to genetic differences

416 between species. We lack such information on the waterlily species studied by us. Kok,

417 Van der Velde \& Landsbergen (1990) showed that phosphorus concentrations in

418 undamaged, recently developed marked floating leaves of Nymphaea alba as well as

419 Nuphar lutea initially were much higher in OW than in VG. In the plots $\mathrm{P}$ and $\mathrm{N}$ of

420 floating leaves of both species have been resorbed by the plant for $70-73 \%$ in OW and

421 61-69 \% in VG (Kok, Van der Velde \& Landsbergen, 1990). This means that the

422 waterlilies belong to the plants with the highest nutrient resorption efficiencies

423 (Hemminga, Marbà \& Stapel, 1999).

425 Conclusions

427 This study will answer the question if there are differences or similarities in production,

428 turnover and other leaf characteristics between waterlily species and if are these

429 differences related to environmental conditions by phenotypic plasticity or can they be 430 considered biological species traits. 
431 Water temperature seems to be a limiting factor for leaf production, not radiation.

432 Analysis of the leaf length time patterns show better fits for the quadratic model, 433 indicating an optimum in leaf length during the growing season. Length-biomass 434 regression equations are obviously influenced by environmental conditions such as low $435 \mathrm{pH}$, low alkalinity and oligotrophic conditions versus high $\mathrm{pH}$, high alkaline and 436 eutrophic conditions.

437 In the case of low $\mathrm{pH}$, low alkalinity and oligotrophy Nuphar lutea and Nymphaea alba 438 showed heavier leaves (ratio leaf length/leaf biomass), a lower number of leaves, a higher 439 leaf life span, a longer growth period, a lower leaf length and leaf area, and leaf biomass. 440 These factors lead also to low floating leaf blade turnover rates (Vegetation period/Mean 441 leaf life span) compared to those in alkaline and nutrient richer environments. However, $442 \mathrm{P} / \mathrm{Bmax}$ differed not much between both species in the various plots and conditions, just 443 as the vegetation and growth period. These can be considered to be regulated by the 444 plants themselves. Nutrient poor, acid conditions prevent leaf loss by inhibiting 445 decomposition, in contrast to decomposition under alkaline and eutrophic conditions 446 where leaf area loss was continuous from the start (Kok, Van der Velde \& Landsbergen, 447 1990).

448 Nymphaea candida clearly deviates in several traits from Nuphar lutea and Nymphaea 449 alba which showed similar leaf characteristics and responses to environmental conditions. 450 Nymphaea candida showed a lower ratio between total and maximum number of leaves, 451 a shorter vegetation period, a lower turnover rate (Vegetation period/Mean life span) and 452 a low $\mathrm{P} / \mathrm{B}_{\max }$. These differences may be caused by adaptation to northern and continental 453 climate conditions, as this species has a very wide distribution from The Netherlands in 
454 the west to Siberia in the east but does not occur south of the Alps (Muntendam, Povel \& 455 Van der Velde, 1996). In contrast, Nymphaea alba occurs all over Europe, including 456 south of the Alps, and Nuphar lutea is widely distributed from Europe to West Siberia, 457 also south of the Alps. The climate zones of the species include roughly the temperate458 boreal zone for Nymphaea candida and the meridional, submeridional and temperate zone 459 for Nymphaea alba and Nuphar lutea (Meusel, Jäger \& Weinhert, 1965.

\section{Acknowledgements}

462

463 We thank M. Ankersmid, R. Kwak, R. de Mooij, H. Peeters, F. Verhoeven, V. Vintges 464 and C.J. Kok for collecting field data, H.J.W.J. van Huet for help with data modeling and 465 E. Jongejans for help with statistics, J. Slippens $\dagger$ (Illustration Department, Radboud 466 University) for making Fig. 1, and the reviewers Gudrun Bornette, Marina Suzuki and 467 one anonymous reviewer for their constructive remarks.

468

469

\section{References}

471 Aramaki, M., Tsuchiya, T. Iwaki, H., 1989. Seasonal changes in photosynthesis and 472 biomass of submerged leaves of Nuphar japonica at Takahama-iri Bay in Lake 473 Kasumigaura. Proceedings of Conference on Limnological Studies at the Kasumigaura 474 Water Research Station. National Institute for Environmental Studies 4: 87-99. (in 475 Japanese). 
477 Arts, G.H.P., Van der Velde, G., J.G.M. Roelofs, J.G.M., Van Swaay, C.A.M., 1990. Suc-

478 cessional changes in the softwater macrophyte vegetation of (sub)atlantic, sandy lowland regions

479 during this century. Freshwater Biology 24: 287-294.

480

481 Brock, T.C.M., 1985. Ecological studies on nymphaeid water plants. D. Phil. Thesis, 482 Catholic University Nijmegen.

483

484 Brock, T.C.M., Arts, G.H.P., Goossen, I.L.M., Rutenfrans, A.H.M., 1983. Structure and 485 annual biomass production of Nymphoides peltata (Gmel.) O. Kuntze (Menyanthaceae). 486 Aquatic Botany 17: 167-188.

487

488 Brock, T.C.M., Boon, J.J., Paffen, B.G.P., 1985. The effects of the season and of water 489 chemistry on the decomposition of Nymphaea alba L.; weight loss and pyrolysis mass 490 spectrometry of the particulate matter. Aquatic Botany 22: 197-229.

491

492 Brock, T.C.M., De Lyon, M.J.H., Van Laar, E.M.J.M., Van Loon, E.M.M., 1985. Field 493 studies on the breakdown of Nuphar lutea (L.) Sm. (Nymphaeaceae), and a comparison 494 of three mathematical models for organic weight loss. Aquatic Botany 21: 1-22.

495

496 Brock, T.C.M., Van der Velde, G., 1983. An autecological study on Hydromyza livens 497 (Fabricius) (Diptera, Scatomyzidae), a fly associated with nymphaeid vegetation 498 dominated by Nuphar. Tijdschrift voor Entomologie 126: 59-90. 
500 Brock, T.C.M., Van der Velde, G., Van de Steeg H.M.,1987. The effects of extreme water level

501 fluctuations on the wetland vegetation of a nymphaeid-dominated oxbow lake in the Nether-

502 lands. In: J. Pokorny, O. Lhotský \& P. Denny (eds.). Waterplants and wetland processes. Archiv

503 für Hydrobiologie Beihefte, Ergebnisse der Limnologie/Advances in Limnology 27: 57-73.

504

505 Chabot, B.F., Hicks, D.J., 1982. The ecology of leaf life spans. Annual Review of Ecology and 506 Systematics 13: 229-259.

507

508 Dacey, J.W.H., 1980. Internal winds in water lilies. An adaptation for life in anaerobic 509 sediments. Science 210 (4473): 1017-1019.

510

511 Dacey, J.W.H., 1981. Pressurized ventilation in the yellow waterlily. Ecology 62: 11375121147.

513

514 Dacey, J.H.W., Klug, M.J., 1979. Methane efflux from lake sediments through water 515 lilies. Science 203 (4386): 1253-1255.

516

517 Den Hartog, C., Van der Velde, G., 1988. Structural aspects of aquatic plant 518 communities. In: J.J. Symoens (ed.). Vegetation of inland waters. Handbook of 519 vegetation science 15: 113-153. Kluwer Academic Publishers, Dordrecht. 520 
521 Gaevskaya, N.S., 1969. The role of higher aquatic plants in the nutrition of animals in

522 fresh-water basins. National Lending Library for Science and Technology, Boston Spa,

523 Yorkshire, England. Vol. I, II and II. 629 pp.

524

525 Hafner, D., Jasprica, N., Caric, M., 2013. Epiphytic diatoms on Nymphaea alba L. leaves 526 in a sub-mediterranean wetland (South Bosnia and Herzegovina). Natura Croatica 22: $527 \quad 319-331$.

528

529 Harper, J.L., 1977. Population biology of plants. Academic Press, London. 892 pp. 530

531 Hemminga, A.A., Marbà, N., Stapel, J., 1999. Leaf nutrient resorption, leaf lifespan and 532 the retention of nutrients in seagrass systems. Aquatic Botany 65: 141-158.

533

534 Howard-Williams, C., 1978. Growth and production of aquatic macrophytes in a south 535 temperate saline lake. Verhandlungen der Internationalen Vereinigung für theoretische 536 und angewandte Limnologie 20: 1153-1158.

538 Hutchinson, G. Evelyn, 1975. A treatise on limnology Vol. III.-Limnological Botany. 539 John Wiley \& Sons. 660 pp.

541 Jacobs, R.P.W.M., 1979. Distribution and aspects of the production and biomass of 542 eelgrass, Zostera marina L., at Roscoff, France. Aquatic Botany 7: 151-172. 
544 Javadi, E., Moattar, F., Karbassi, A.R., Monavari, S.M., 2010. Removal of lead, cadmium

545 and manganese from liquid solution using water lily (Nymphaea alba). Journal of Food,

546 Agriculture and Environment 8: 1220-1225.

547

548 Jeppesen, E., Søndergaard, M., Christoffersen, K. (eds.), 1998. The structuring role of

549 submerged macrophytes in lakes. Ecological Studies 131: 1-423. Springer-Verlag, New

550 York, Berlin, Heidelberg.

551

552 Kok, C.J., 1993. Decomposition of floating leaves of Nymphaea alba L. under alkaline 553 and acid conditions. D. Phil. Thesis, Catholic University Nijmegen.

555 Kok, C.J., Hof, C.H.J., Lenssen, J.P.M., Van der Velde, G., 1992. The influence of pH on

556 concentrations of protein and phenolics and resource quality of decomposing floating leaf

557 material of Nymphaea alba L. (Nymphaeaceae) for the detritivore Asellus aquaticus (L.).

558 Oecologia 91: 229-234.

559

560 Kok, C.J., Van der Velde, G., 1991. The influence of selected water quality parameters on

561 the decay and exoenzymatic activity of detritus of floating leaf blades of Nymphaea alba

562 L. in laboratory experiments. Oecologia 88: 311-316.

563

564 Kok, C.J., Van der Velde, G., Landsbergen, K.M., 1990. Production, nutrient dynamics

565 and initial decomposition of floating leaves of Nymphaea alba L., and Nuphar lutea (L.)

566 Sm. (Nymphaeaceae) in alkaline and acid waters. Biogeochemistry 11: 235-250. 
568 Kowalik, M., 2012. Fungi and chromistan fungi associated with plants White Water Lily

569 Nymphaea alba L. during the vegetation season. Acta Scientiarum Polonorum Hortorum 570 Cultus 11: 167-172.

571

572 Kunii, H., Aramaki, M., 1992. Annual net production and life span of floating leaves in 573 Nymphaea tetragona Georgi: a comparison with other floating-leaved macrophytes. 574 Hydrobiologia 242: 185-193.

575

576 Lavid, N., Schwartz, A., Lewinsohn, E, Tel-Or, E., 2001. Phenols and phenol oxidases 577 are involved in cadmium accumulation in the water plants Nymphoides peltata 578 (Menyanthaceae) and Nymphaeae (Nymphaeaceae). Planta 214: 189-195.

579

580 Luther, H., 1983. On life forms, and above-ground and underground biomass of aquatic 581 macrophytes. Acta Botanica Fennica 123: 1-23.

582

583 Meusel, H.E., Jäger, E., Weinhert, E., 1965. Vergleichende Chorologie der 584 Zentraleuropäischen Flora. Vol. 1: Text 583 pp., Vol. 2: Karten , 1-258. VEB Gustav 585 Fischer Verlag, Jena.

587 Muntendam, J.B., Povel, G.D.E., Van der Velde, G., 1996. Morphometric patterns in the 588 Nymphaea alba-candida complex. Acta Botanica Neerlandica 45: 279-302. 
590 Nienhuis, P.H., De Bree, B.H.H., 1980. Production and growth dynamics of eelgrass

591 (Zostera marina) in brackish Lake Grevelingen (The Netherlands). Netherlands Journal

592 of Sea Research 14: 102-118.

593

594 Paillison, J.-M., Marion, L., 2001. Interaction between coot (Fulica atra) and waterlily 595 (Nymphaea alba) in a lake: the indirect impact of foraging. Aquatic Botany 71: 209-216. 596

597 R Core Team, 2015. R: A language and environment for statistical computing. R 598 Foundation for Statistical Computing, Vienna, Austria. URL https://www.R-project.org/. 599

600 Ribaudo, C., Bartoli, M., Longhi, D., Castaldi, S., Neubauer, S.C., Viaroli, P., 2012. $\mathrm{CO}_{2}$ 601 and $\mathrm{CH}_{4}$ fluxes across a Nuphar lutea (L.) Sm. stand. Journal of Limnology 71: 200-210. 602

603 Smits, A.J.M., De Lyon, M.J.H., Van der Velde, G., Steentjes, P.L.M., Roelofs, 604 J.G.M.,1988. Distribution of three nymphaeid macrophytes (Nymphaea alba L., Nuphar 605 lutea (L.) Sm. and Nymphoides peltata (Gmel.) O. Kuntze) in relation to alkalinity and 606 uptake of inorganic carbon. Aquatic Botany 32: 45-62.

607

608 Smits, A.J.M., Laan, P., Thier, R.H. Van der Velde, G., 1990. Root aerenchyma, oxygen leakage 609 patterns and alcoholic fermentation ability of the roots of some nymphaeid and isoetid 610 macrophytes in relation to the sediment type of their habitat. Aquatic Botany 38: 3-17. 611 
612 Snir, A., Gurevitz, M., Marcus, I., 2006. Alterations in Rubisco activity and in stomatal

613 behavior induce a daily rhythm in photosynthesis of aerial leaves in the amphibious plant

614 Nuphar lutea. Photosynthesis Research 90: 233-242.

615

616 Twilley, R.R., Blanton, L.R., Brinson, M.M., Davis, G.J., 1985. Biomass production and 617 nutrient cycling in aquatic macrophyte communities of the Chowan River, North 618 Carolina. Aquatic Botany 22: 231-252.

619

620 Van der Velde, G., 1980. Studies in nymphaeid-dominated systems. D. Phil. Thesis, 621 Catholic University Nijmegen.

622

623 Van der Velde, G., 1981. A project on nymphaeid-dominated systems. Hydrobiological 624 Bulletin 15: 185-189.

625

626 Van der Velde, G., Brock, T.C.M., 1980. The life history and habits of Notiphila 627 brunnipes Robineau-Desvoidy (Diptera, Ephydridae), an autoecological study on a fly 628 associated with nymphaeid vegetations. Tijdschrift voor Entomologie 123: 105-127.

629

630 Van der Velde, G., Meuffels, H.J.G., Heine, M., Peeters, P.M.P.M., 1985. Dolicho631 podidae (Diptera) of a nymphaeid-dominated system in the Netherlands: species compo632 sition, diversity, spatial and temporal distribution. Aquatic Insects 7: 189-207. 633 
634 Van der Velde, G., Custers, C.P.C., De Lyon, M.J.H., 1986. The distribution of four 635 nymphaeid species in the Netherlands in relation to selected abiotic factors. Proceedings 636 EWRS/AAB $7^{\text {th }}$ Symposium on Aquatic Weeds, 1986: 363-368.

637

638 Van der Velde, G., Kok, C.J., Van Vorstenbosch, H.J.W.T., 1989. Bagous rotundicollis, 639 new for The Netherlands, feeding on water lily leaves (Coleoptera: Curculionidae). 640 Entomologische Berichten, Amsterdam 49: 57-60

641

642 Van der Velde, G., Peelen-Bexkens, P.M.M., 1983. Production and biomass of floating 643 leaves of two species of Nymphaeaceae in two Dutch waters. Proceedings International 644 Symposium Aquatic Macrophytes, Nijmegen, 18-23 September 1983: 230-235. 645

646 Vergeer, L.H.T., Van der Velde, G., 1997. The phenolic content of daylight -exposed and 647 shaded floating leaves of water lilies (Nymphaeaceae) in relation to infection by fungi. 648 Oecologia 112: 481-484.

649

650 Wiik, E., Bennion, H., Sayer, C.D., Davidson, T.A., McGowan, S., Patmore, I.R. , 651 Clarke, S.J., 2015. Ecological sensitivity of marl lakes to nutrient enrichment, evidence 652 from Hawer Water, UK. Freshwater Biology 60: 2226-2247.

653

654 Willmer, P.G., 1982. Hygrothermal determinants of insect activity patterns: Diptera of 655 water-lily leaves. Ecological Entomology 7: 221-231. 656 
657 Zbikowski, J., Kobak, J., Zbikowska, E., 2010. Is Nuphar lutea (L.) Sm. a structuring 658 factor for macrozoobenthos and selected abiotic parameters of water and bottom 659 sediments throughout the year? Aquatic Ecology 44: 709-721.

660 


\section{Tables}

662

663 Table 1 Physico-chemical characteristics of the three investigated water bodies. Chemical

664 characteristics from Brock, Boon \& Paffen (1985) and Kok, Van der Velde \&

665 Landsbergen (1990).

666

\begin{tabular}{|c|c|c|c|}
\hline & Haarsteegse Wiel (HW) & Oude Waal (OW) & Voorste Goorven (VG) \\
\hline Area (ha) & 18 & 25 & 5 \\
\hline Depth (m) & 17 & 1.5 & 2 \\
\hline Water level fluctuations & Low & High & Low \\
\hline Stratification & $\begin{array}{l}\text { Yes } \\
\text { (summer, thermocline at 4-6m) }\end{array}$ & No & No \\
\hline Hydrology & $\begin{array}{l}\text { Precipitation/evaporation } \\
\text { Seepage }\end{array}$ & $\begin{array}{l}\text { Precipitation/evaporation } \\
\text { Upward seepage } \\
\text { River water overflow }\end{array}$ & $\begin{array}{l}\text { Precipitation/evaporation } \\
\text { Upward seepage }\end{array}$ \\
\hline Wind and wave action & Low & Moderate & Moderate \\
\hline Bottom & Sand/sapropelium & Sand/clay/sapropelium & Sand/sapropelium \\
\hline Trophic status & Eutrophic & Highly eutrophic & Oligotrophic \\
\hline Chemical characteristics & & & \\
\hline $\begin{array}{l}\left.\text { Alkalinity (meq. } \mathrm{L}^{-1}\right) \\
\mathrm{pH}\end{array}$ & $\begin{array}{l}1.5 \\
7.1-8.5\end{array}$ & $\begin{array}{l}5.2 \\
6.7-8.3\end{array}$ & $\begin{array}{l}0.0-0.07 \\
4.7-5.5\end{array}$ \\
\hline Sampling programme & 1977 & 1977 & 1988 \\
\hline Plots: species, depth $(\mathrm{m}) \backslash$ & $\begin{array}{l}\text { Nuphar lutea, } 1.5 \\
\text { Nymphaea candida, } 2.5\end{array}$ & $\begin{array}{l}\text { Nuphar lutea, } 1.5 \\
\text { Nymphaea alba, } 1.5\end{array}$ & $\begin{array}{l}\text { Nuphar lutea, } 2 \\
\text { Nymphaea alba, } 2\end{array}$ \\
\hline
\end{tabular}

667

668 
669 Table 2 Leaf characteristics of Nuphar lutea (L.) Sm., Nymphaea alba L. and Nymphaea

670 candida Presl in Haarsteegse Wiel (HW), Oude Waal (OW) and Voorste Goorven (VG).

671

\begin{tabular}{|c|c|c|c|c|c|c|c|}
\hline \multicolumn{2}{|l|}{ Species } & \multicolumn{3}{|c|}{ Nuphar lutea } & \multicolumn{2}{|c|}{ Nymphaea alba } & \multirow{3}{*}{$\begin{array}{l}\text { Nymphaea candida } \\
\text { HW } \\
1977\end{array}$} \\
\hline Location & & HW & OW & VG & OW & VG & \\
\hline Year & & 1977 & 1977 & 1988 & 1977 & 1988 & \\
\hline \multicolumn{2}{|l|}{ Number of leaves } & & & & & & \\
\hline Total & $\mathrm{m}^{-2} \cdot \mathrm{yr}^{-1}$ & 77 & 59 & 22 & 108 & 80 & 43 \\
\hline Maximum & $m^{-2}$ & 36 & 28 & 10 & 50 & 34 & 31 \\
\hline Mean new per day & & 0.39 & 0.34 & 0.12 & 0.60 & 0.44 & 0.32 \\
\hline Date(s) of maximum & & Aug. 2 & Aug. 19 & July 28 & July 13 & Aug. 11 & Aug. 2 \\
\hline & & & Aug. 25 & Aug. 18 & $\begin{array}{l}\text { July } 20 \\
\text { Aug. } 11\end{array}$ & & \\
\hline \multicolumn{8}{|l|}{ Leaf life span } \\
\hline Maximum & $\mathrm{d}$ & 86 & 73 & 91 & 77 & 84 & 92 \\
\hline Minimum & d & 7 & 12 & 7 & 7 & 7 & 7 \\
\hline Mean & d & 42.75 & 37.93 & 47.73 & 40.46 & 46.46 & 46.28 \\
\hline Standard deviation & d & 19.93 & 13.03 & 18.28 & 18.09 & 18.48 & 20.17 \\
\hline \multicolumn{8}{|l|}{ Vegetation period } \\
\hline Length & $\mathrm{d}$ & 199 & 175 & 183 & 180 & 183 & 135 \\
\hline Begin date & & May 10 & May 11 & Apr. 28 & May 11 & Apr. 28 & June 7 \\
\hline End date & & Nov. 24 & Nov. 1 & Oct. 27 & Nov. 6 & Oct. 27 & Oct. 19 \\
\hline \multicolumn{8}{|l|}{ Growth period } \\
\hline Length & d & 127 & 120 & 134 & 120 & 134 & 71 \\
\hline Begin date & & May 10 & May 11 & Apr. 28 & May 11 & Apr. 28 & June 7 \\
\hline End date & & Sep. 13 & Sep. 7 & Sep. 8 & Sep. 7 & Sep. 8 & Aug. 16 \\
\hline \multicolumn{8}{|l|}{ Leaf length } \\
\hline Maximum & $\mathrm{cm}$ & 39.0 & 39.0 & 33.2 & 34.0 & 25.2 & 23.5 \\
\hline Minimum & $\mathrm{cm}$ & 22.0 & 14.0 & 14.5 & 5.5 & 7.3 & 7.5 \\
\hline Range & $\mathrm{cm}$ & 17.0 & 25.0 & 18.7 & 28.5 & 17.9 & 16.0 \\
\hline Mean begin & $\mathrm{cm}$ & 30.79 & 31.05 & 23.09 & 21.86 & 17.33 & 17.88 \\
\hline Standard deviation & $\mathrm{cm}$ & 2.48 & 4.21 & 4.97 & 6.44 & 3.19 & 2.69 \\
\hline Mean end & $\mathrm{cm}$ & 32.29 & 32.81 & 24.27 & 24.28 & 18.86 & 19.30 \\
\hline Standard deviation & $\mathrm{cm}$ & 2.68 & 4.33 & 5.38 & 7.11 & 3.32 & 3.04 \\
\hline Range & $\mathrm{cm}$ & 1.5 & 1.8 & 1.1 & 2.4 & 1.6 & 1.5 \\
\hline \multicolumn{8}{|l|}{ Leaf area } \\
\hline Tot. pot. & $\mathrm{m}^{2} \cdot \mathrm{m}^{-2} \cdot \mathrm{yr}^{-1}$ & 4.97 & 3.99 & 0.84 & 5.30 & 2.31 & 1.12 \\
\hline Max. pot. & $\mathrm{m}^{2} \cdot \mathrm{m}^{-2}$ & 2.39 & 1.93 & 0.39 & 2.79 & 1.03 & 0.83 \\
\hline Max. act. & $\mathrm{m}^{2} \cdot \mathrm{m}^{-2}$ & 1.98 & 1.54 & 0.37 & 2.34 & 1.00 & 0.77 \\
\hline Max. phot. & $\mathrm{m}^{2} \cdot \mathrm{m}^{-2}$ & 1.72 & 1.21 & 0.32 & 2.06 & 0.98 & 0.62 \\
\hline Mean pot. per day & $\mathrm{m}^{2} \cdot \mathrm{m}^{-2} \cdot \mathrm{d}^{-1}$ & 0.0250 & 0.0228 & 0.0046 & 0.0295 & 0.0126 & 0.0083 \\
\hline Mean pot. per leaf & $\mathrm{m}^{2} \cdot \mathrm{m}^{-2}$ & 0.0645 & 0.0676 & 0.0384 & 0.0497 & 0.0288 & 0.0260 \\
\hline Standard deviation & $\mathrm{m}^{2} \cdot \mathrm{m}^{-2}$ & 0.0104 & 0.0158 & 0.0155 & 0.0239 & 0.0092 & 0.0075 \\
\hline Max. pot. area date & & Sep. 6 & Aug. 19 & July 28 & Aug. 11 & July 21 & Aug. 2 \\
\hline Max. act. area date & & Aug. 2 & Aug. 19 & July 28 & Aug. 11 & July 14 & Aug. 2 \\
\hline Max. phot. area date & & Aug. 16 & Aug. 19 & July 28 & Aug. 11 & July 14 & July 19 \\
\hline \multicolumn{8}{|l|}{ Leaf biomass } \\
\hline Tot. pot. & $\mathrm{g}$ AFDW. $\mathrm{m}^{-2} \cdot \mathrm{yr}^{-1}$ & 447 & 245 & 111 & 348 & 312 & 96 \\
\hline Max. pot. & $\mathrm{g}$ AFDW.m $\mathrm{m}^{-2}$ & 215 & 118 & 51 & 183 & 139 & 71 \\
\hline Max. act. & $\mathrm{g}$ AFDW.m. ${ }^{-2}$ & 178 & 95 & 49 & 153 & 136 & 66 \\
\hline Max. phot. & g AFDW.m ${ }^{-2}$ & 155 & 74 & 43 & 135 & 133 & 54 \\
\hline Mean pot. per day & $\mathrm{g}$ AFDW. $\mathrm{m}^{-2} \cdot \mathrm{d}^{-1}$ & 2.25 & 1.40 & 0.61 & 1.93 & 1.71 & 0.71 \\
\hline Mean pot. per leaf & g AFDW.m-2 & 5.81 & 4.15 & 5.06 & 3.22 & 3.91 & 2.24 \\
\hline Standard deviation & $\mathrm{g}$ AFDW.m $\mathrm{m}^{-2}$ & 0.94 & 0.97 & 2.04 & 1.49 & 1.25 & 0.65 \\
\hline Max. pot. biomass date & & Sep. 6 & Aug. 19 & July 28 & Aug. 11 & July 21 & Aug. 2 \\
\hline Max. act. biomass date & & Aug. 2 & Aug. 19 & July 28 & Aug. 11 & July 14 & Aug. 2 \\
\hline Max. phot. biomass date & & Aug. 16 & Aug. 19 & July 28 & Aug. 11 & July 14 & July 19 \\
\hline
\end{tabular}

672 
673 Table 3 P-values of Welch's t-test for the leaf life span between species, where $\mathrm{Nl}=$

674 Nuphar lutea, $\mathrm{Na}=$ Nymphaea alba, $\mathrm{Nc}=$ Nymphaea candida, $\mathrm{HW}=$ Haarsteegse Wiel,

$675 \mathrm{OW}=$ Oude Waal, $\mathrm{VG}=$ Voorste Goorven. $* *=0.001<\mathrm{p}<0.01, *=0.01<\mathrm{p}<0.05$

676

\begin{tabular}{|l|l|l|l|l|l|l|}
\hline & Nl HW & Nl OW & Nl VG & Na OW & Na VG & Nc HW \\
\hline Nl HW & --- & 0.09140 & 0.2775 & 0.4247 & 0.2289 & 0.359 \\
\hline Nl OW & & --- & $0.02849^{*}$ & 0.2994 & $0.001758^{* *}$ & $0.02035^{*}$ \\
\hline Nl VG & & & --- & 0.09918 & 0.7761 & 0.7719 \\
\hline Na OW & & & & --- & $0.02768^{*}$ & 0.1043 \\
\hline Na VG & & & & & --- & 0.9606 \\
\hline Nc HW & & & & & & -- \\
\hline
\end{tabular}

677

678 
679 Table 4 Leaf length in time regression equations (equations (1) and (2)) with correlation 680 coefficients for begin and end lengths. HW = Haarsteegse Wiel, OW = Oude Waal, VG=

681 Voorste Goorven. $\mathrm{N}=$ total number of leaves per $\mathrm{m}^{2}$ per year, $\mathrm{B}=$ begin length of leaves,

$682 \mathrm{E}=$ end length of leaves, $\mathrm{L}=$ leaf length $(\mathrm{cm}), \mathrm{t}=$ time in days (where April $1=0$ ),

$683 \mathrm{r}=$ correlation, $\mathrm{p}=$ significance level (n.s.= not significant). See also Fig. 4.

684

\begin{tabular}{|c|c|c|c|c|c|c|c|c|c|}
\hline Site & Year & $\mathrm{N}$ & $\mathrm{B} / \mathrm{E}$ & Linear model & $\mathrm{r}$ & $\mathrm{p}$ & Quadratic model & $\mathrm{r}$ & $\mathrm{p}$ \\
\hline \multicolumn{10}{|c|}{ Nuphar lutea } \\
\hline \multirow[t]{2}{*}{ HW } & 1977 & 77 & B & $\mathrm{L}=28.74+0.034 \mathrm{t}$ & 0.53 & $<0.05$ & $\mathrm{~L}=20.00+0.225 \mathrm{t}-0.0009 \mathrm{t}^{2}$ & 0.70 & $<0.05$ \\
\hline & & & E & $\mathrm{L}=27.68+0.037 \mathrm{t}$ & 0.63 & $<0.01$ & $\mathrm{~L}=22.55+0.115 \mathrm{t}-0.0003 \mathrm{t}^{2}$ & 0.67 & $<0.01$ \\
\hline \multirow[t]{2}{*}{ OW } & 1977 & 59 & B & $\mathrm{L}=29.10+0.042 \mathrm{t}$ & 0.53 & $<0.05$ & $\mathrm{~L}=24.56+0.145 \mathrm{t}-0.0005 \mathrm{t}^{2}$ & 0.57 & $<0.05$ \\
\hline & & & $\mathrm{E}$ & $\mathrm{L}=30.73+0.033 \mathrm{t}$ & 0.59 & $<0.01$ & $\mathrm{~L}=22.47+0.166 \mathrm{t}-0.0005 \mathrm{t}^{2}$ & 0.68 & $<0.01$ \\
\hline \multirow[t]{2}{*}{ VG } & 1988 & 22 & B & $\mathrm{L}=-29.83+0.044 \mathrm{t}$ & -0.44 & n.s. & $\mathrm{L}=17.04+0.268 \mathrm{t}-0.0016 \mathrm{t}^{2}$ & 0.72 & $<0.05$ \\
\hline & & & $\mathrm{E}$ & $\mathrm{L}=-31.31+0.024 \mathrm{t}$ & -0.37 & n.s. & $\mathrm{L}=22.94+0.106 \mathrm{t}+0.0005 \mathrm{t}^{2}$ & 0.44 & n.s. \\
\hline \multicolumn{10}{|c|}{ Nymphaea alba } \\
\hline \multirow[t]{2}{*}{ OW } & 1977 & 108 & B & $\mathrm{L}=24.48+0.022 \mathrm{t}$ & 0.22 & n.s. & $\mathrm{L}=-2.79+0.628 \mathrm{t}+0.0030 \mathrm{t}^{2}$ & 0.93 & $<0.001$ \\
\hline & & & E & $\mathrm{L}=23.36+0.035 \mathrm{t}$ & 0.42 & $<0.05$ & $\mathrm{~L}=4.08+0.346 \mathrm{t}-0.0011 \mathrm{t}^{2}$ & 0.72 & $<0.001$ \\
\hline \multirow[t]{2}{*}{ VG } & 1988 & 80 & B & $\mathrm{L}=18.34+0.008 \mathrm{t}$ & 0.11 & n.s. & $\mathrm{L}=4.11+0.362 \mathrm{t}-0.0019 \mathrm{t}^{2}$ & 0.97 & $<0.001$ \\
\hline & & & $\mathrm{E}$ & $\mathrm{L}=19.94+0.009 \mathrm{t}$ & 0.18 & n.s. & $\mathrm{L}=4.70+0.281 \mathrm{t}-0.0011 \mathrm{t}^{2}$ & 0.86 & $<0.001$ \\
\hline \multicolumn{3}{|c|}{ Nymphaea candida } & & & & & & & \\
\hline HW & 1977 & 43 & B & $\mathrm{L}=20.68+0.021 \mathrm{t}$ & -0.18 & n.s. & $\mathrm{L}=-46.47+1.300 \mathrm{t}-0.0063 \mathrm{t}^{2}$ & 0.95 & $<0.001$ \\
\hline & & & $\mathrm{E}$ & $\mathrm{L}=15.22+0.039 \mathrm{t}$ & 0.68 & $<0.05$ & $\mathrm{~L}=2.37+0.223 \mathrm{t}-0.0006 \mathrm{t}^{2}$ & 0.76 & $<0.05$ \\
\hline
\end{tabular}

685

686 
687 Table 5 Length-area regression equations (equation (5)), used for the calculation of 688 potential leaf area from leaf length (Van der Velde and Peelen-Bexkens, 1983), where A $689=$ area and $\mathrm{L}=$ leaf length.

690

\begin{tabular}{|l|l|}
\hline Species & Equation \\
\hline Nuphar lutea & $\mathrm{A}=0.623 \mathrm{~L}^{2}$ \\
\hline Nymphaea alba & $\mathrm{A}=0.788 \mathrm{~L}^{2}$ \\
\hline Nymphaea candida & $\mathrm{A}=0.695 \mathrm{~L}^{2}$ \\
\hline
\end{tabular}

691

692 
693 Table 6 Length-biomass regression equations (equation (6)), used for the calculation of 694 potential leaf biomass from leaf length (Van der Velde and Peelen-Bexkens, 1983), where $695 \mathrm{~B}=$ biomass and $\mathrm{L}=$ leaf length, $\mathrm{OW}=$ Oude Waal, $\mathrm{HW}=$ Haarsteegse Wiel, $\mathrm{VG}=$ 696 Voorste Goorven.

697

\begin{tabular}{|l|l|l|l|l|l|l|}
\hline Species & Location, year & $\mathrm{N}$ & Equation & S.E. & $\mathrm{r}^{2}$ & $\mathrm{p}$ \\
\hline Nuphar lutea & OW 1977 & 27 & $\mathrm{~B}=0.00382 \mathrm{~L}^{2}$ & 0.330 & 0.99 & $<0.001$ \\
& HW 1977 & 10 & $\mathrm{~B}=0.00561 \mathrm{~L}^{2}$ & 0.324 & 0.99 & $<0.001$ \\
& VG 1988 & & $\mathrm{~B}=0.00821 \mathrm{~L}^{2}$ & & & \\
& & & & & & \\
\hline Nymphaea alba & OW $1976 / 1977$ & 84 & $\mathrm{~B}=0.00510 \mathrm{~L}^{2}$ & 0.339 & 0.98 & $<0.001$ \\
& VG 1988 & & $\mathrm{~B}=0.01068 \mathrm{~L}^{2}$ & & & \\
\hline Nymphaea candida & HW 1977 & 10 & $\mathrm{~B}=0.00598 \mathrm{~L}^{2}$ & 0.229 & 0.98 & $<0.001$ \\
\hline
\end{tabular}

698

699 
700 Table 7 Turnover rates and other ratios of leaf characteristics of Nuphar lutea (L.) Sm.,

701 Nymphaea alba L. and Nymphaea candida Presl in Haarsteegse Wiel (HW), Oude Waal (OW)

702 and Voorste Goorven (VG). See also Table 2.

703

\begin{tabular}{|c|c|c|c|c|c|c|c|}
\hline Species & & Nupha & & & Nympl & & Nymphaea candida \\
\hline Location & & HW & OW & VG & OW & $\mathrm{VG}$ & HW \\
\hline Year & & 1977 & 1977 & 1988 & 1977 & 1988 & 1977 \\
\hline $\begin{array}{l}\text { Turnover rate } \\
\text { Vegetation period/Mean leaf life span }\end{array}$ & & 4.63 & 4.61 & 3.81 & 4.39 & 3.89 & 2.94 \\
\hline Turnover rate $\left(\mathrm{P} / \mathrm{B}_{\max }\right)$ & & & & & & & \\
\hline Tot. pot. leaf biomass/Max. pot. leaf biomass & $\mathrm{yr}^{-1}$ & 2.08 & 2.08 & 2.18 & 1.90 & 2.25 & 1.35 \\
\hline Total number of leaves/Max. number of leaves & & 2.14 & 2.11 & 2.20 & 2.16 & 2.35 & 1.39 \\
\hline Mean leaf life span/Total number of leaves & & 0.56 & 0.64 & 2.18 & 0.38 & 0.56 & 1.07 \\
\hline Growth period/Vegetation period & & 0.64 & 0.69 & 0.73 & 0.66 & 0.73 & 0.53 \\
\hline Leaf area & & & & & & & \\
\hline Max. pot. / Tot. pot. & $\%$ & 48 & 48 & 46 & 53 & 46 & 74 \\
\hline Max. act. / Tot. pot. & $\%$ & 40 & 39 & 44 & 44 & 43 & 69 \\
\hline Max. phot. / Tot. pot. & $\%$ & 35 & 30 & 38 & 39 & 42 & 56 \\
\hline Leaf biomass & & & & & & & \\
\hline Max. pot. / Tot. pot. & $\%$ & 48 & 48 & 46 & 53 & 45 & 74 \\
\hline Max. act. / Tot. pot. & $\%$ & 40 & 39 & 44 & 44 & 44 & 69 \\
\hline Max. phot. / Tot. pot. & $\%$ & 35 & 30 & 39 & 39 & 43 & 56 \\
\hline Leaf area/Leaf biomass & & & & & & & \\
\hline for Max pot. & & 0.011 & 0.016 & 0.008 & 0.015 & 0.007 & 0.012 \\
\hline for Max act. & & 0.011 & 0.016 & 0.008 & 0.015 & 0.007 & 0.012 \\
\hline for Max phot. & & 0.011 & 0.016 & 0.007 & 0.015 & 0.007 & 0.011 \\
\hline
\end{tabular}


705

706

707

708

709

710
Figures

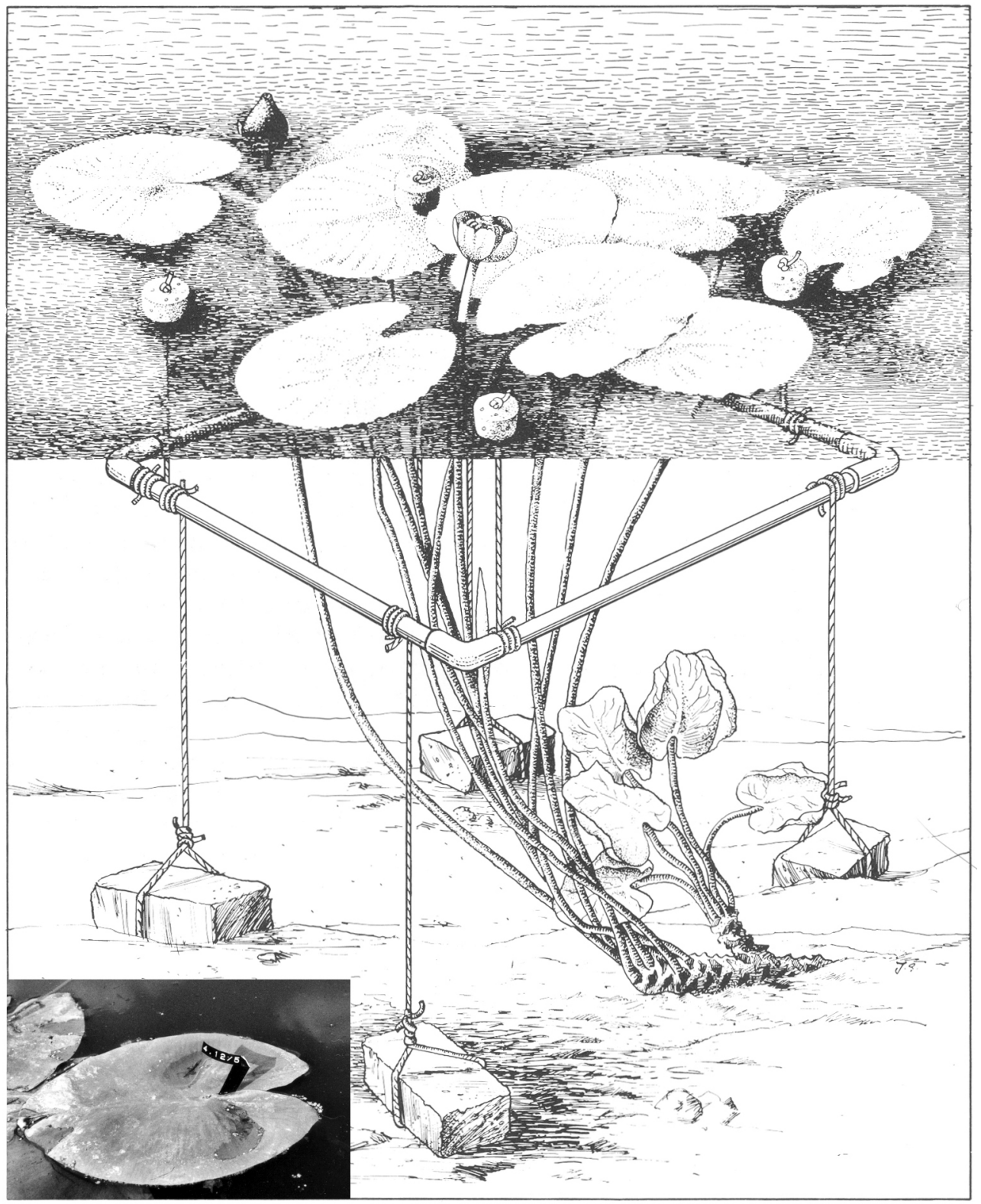

Fig. 1 A plot of Nuphar lutea (L.) Sm. bordered by an anchored frame provided with cork floaters. The insert shows a tagged floating leaf with the tag code clearly visible. 


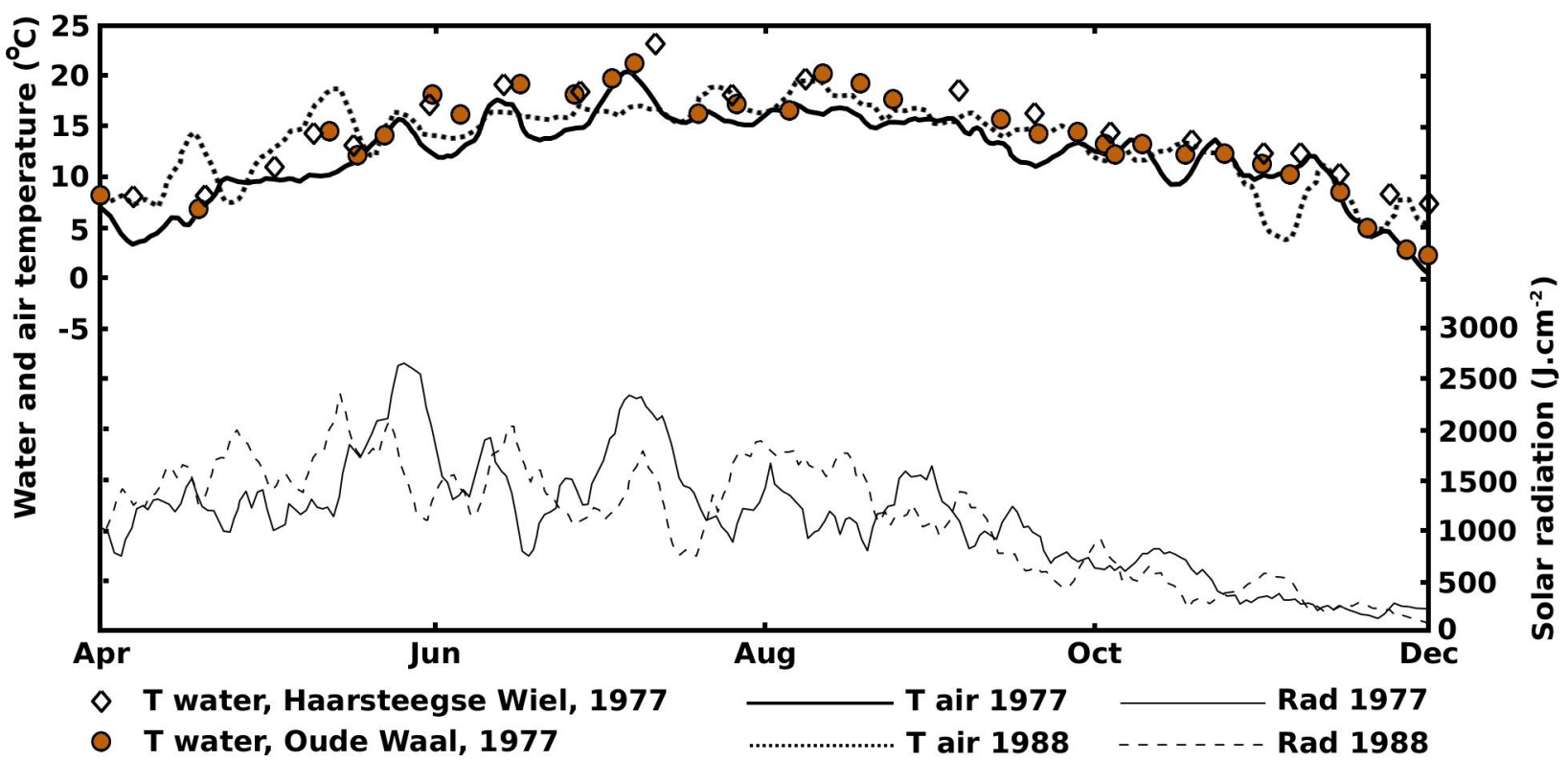

712

713 Fig. 2 Above, scale left: water temperature measured in Haarsteegse Wiel (HW) and

714 Oude Waal (OW) in 1977 and averaged air temperature in 1977 and 1988 based on data

715 collected by the Royal Netherlands Meteorological Institute. Below, scale right: averaged

716 solar radiation in 1977 and 1988 based on data collected by the Royal Netherlands

717 Meteorological Institute.

718 
719
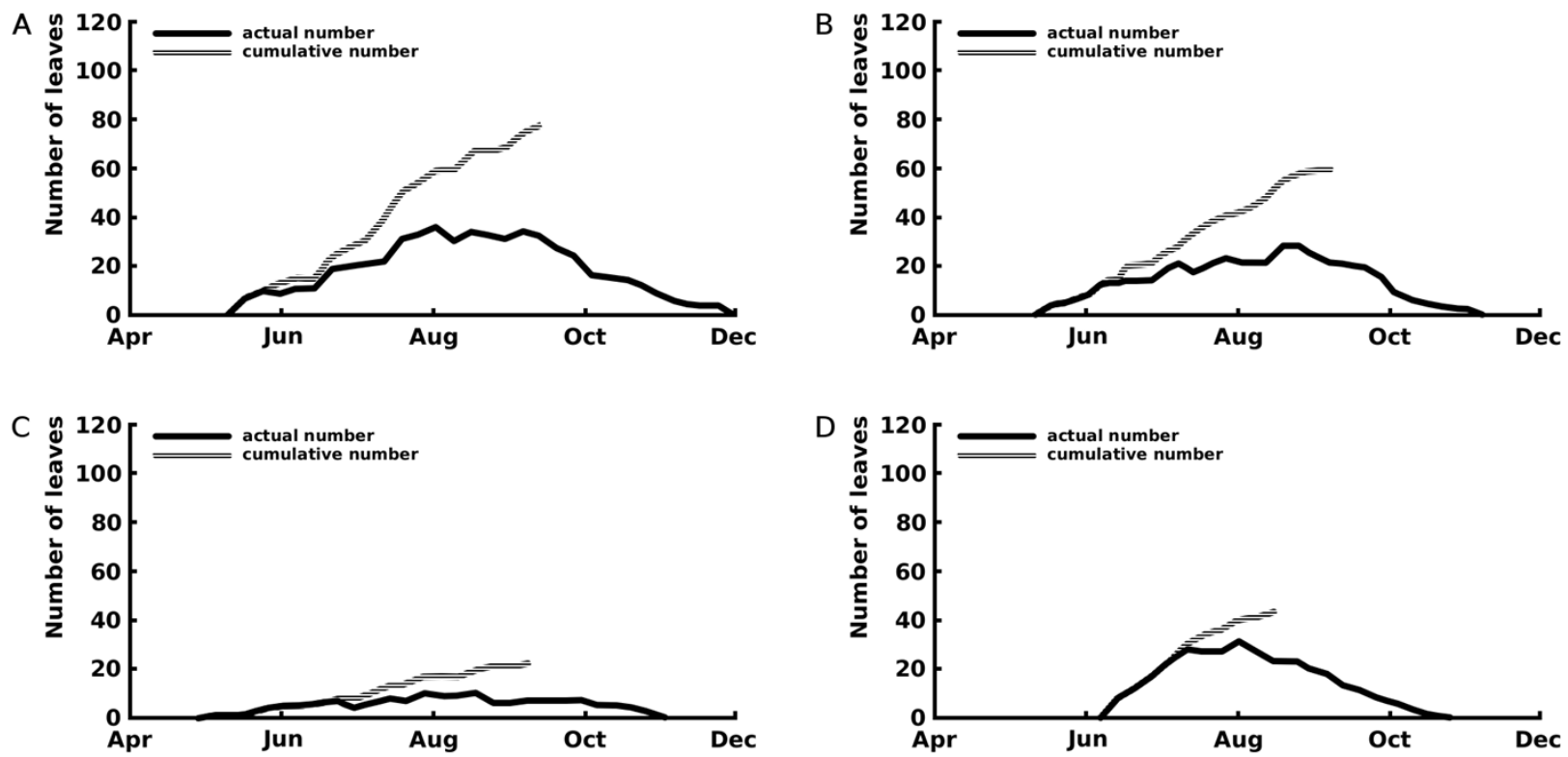

720
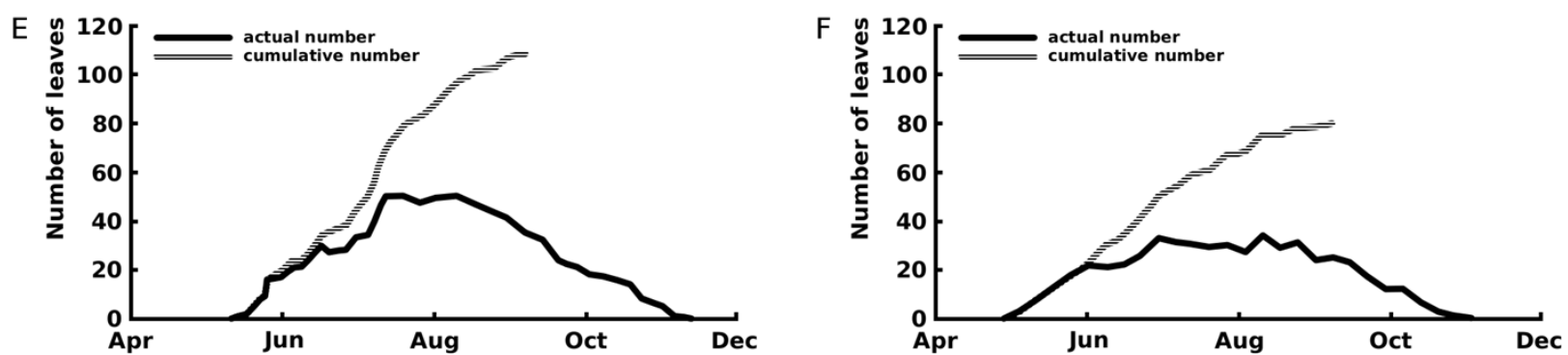

722 Fig. 3 Number of leaves: seasonal patterns of the cumulative (grey line) and actual (dark line)

723 number of leaves of one rhizome apex per plot. The period with actual number of leaves is the

724 vegetation period, the period with cumulative number of leaves indicates the period with newly appeared leaves the growth period. Where $\mathrm{A}=$ Nuphar lutea in Haarsteegse Wiel 1977, $\mathrm{B}=$ Nuphar lutea in Oude Waal 1977, C = Nuphar lutea in Voorste Goorven 1988, D = Nymphaea candida in Haarsteegse Wiel 1977, E = Nymphaea alba in Oude Waal 1977, F = Nymphaea alba

728 in Voorste Goorven 1988. 

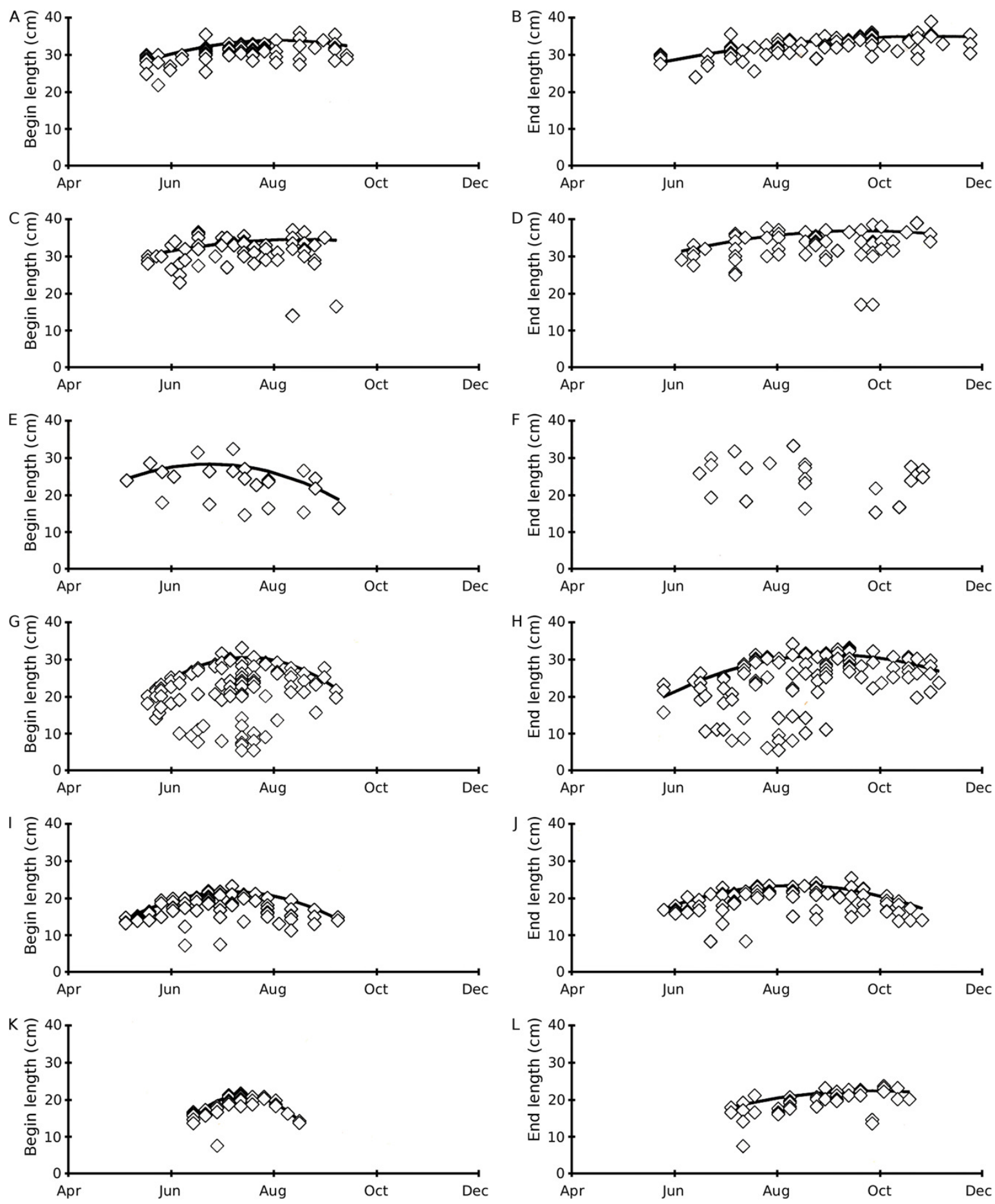

Fig. 4 Scatter plots of observed begin and end leaf lengths over time and regression lines

733 of predicted maximum values using quadratic regression equation (6). Where $\mathrm{A}-\mathrm{B}=$

734 Nuphar lutea in Haarsteegse Wiel 1977, C-D =Nuphar lutea in Oude Waal 1977, E-F =

735 Nuphar lutea in Voorste Goorven 1988, G-H = Nymphaea candida in Haarsteegse Wiel 
736 1977, I-J = Nymphaea alba in Oude Waal 1977, K-L = Nymphaea alba in Voorste

737 Goorven 1988.

738
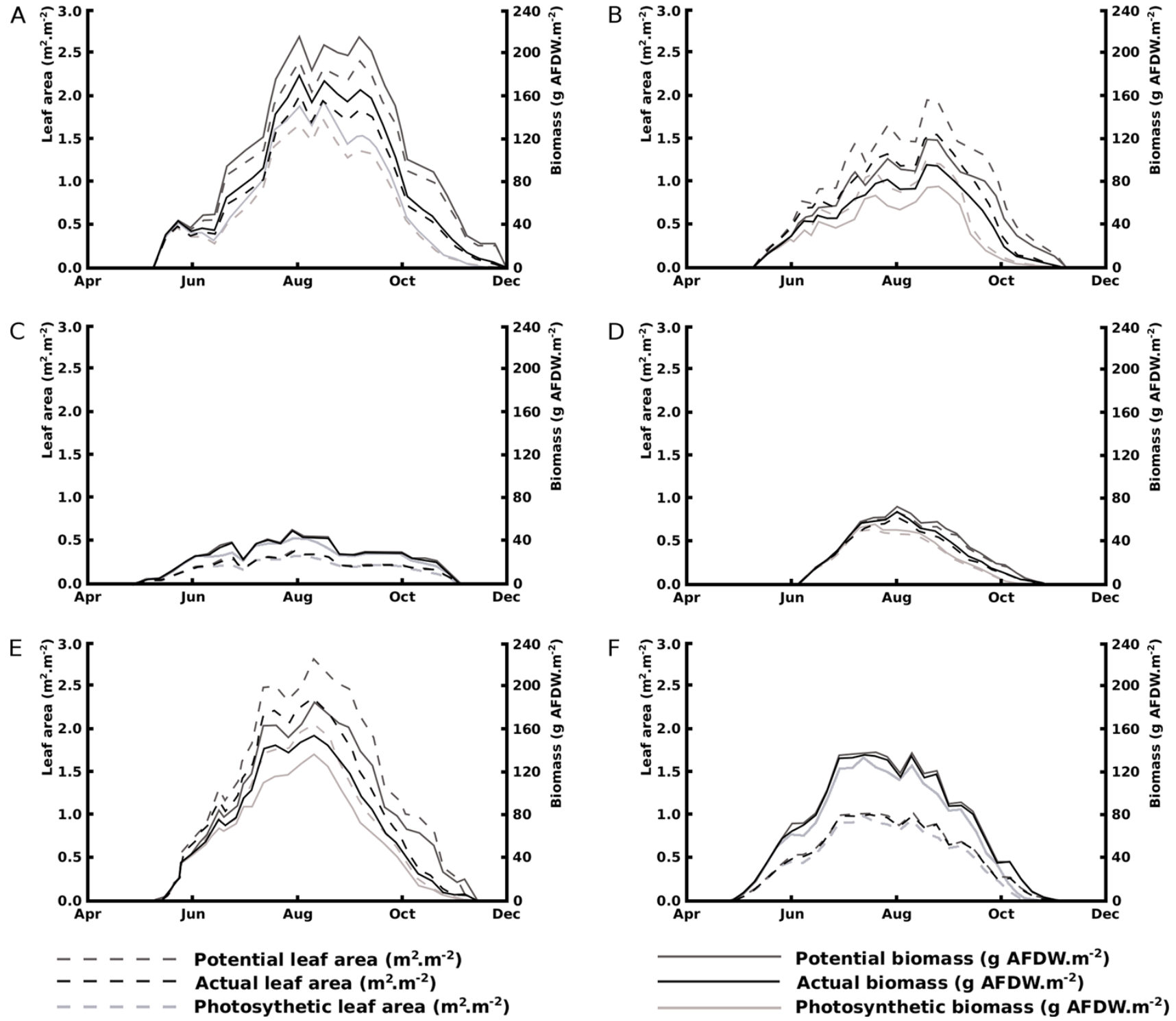

740

741 Fig. 5 Changes over time of potential, actual and photosynthetic leaf area and biomass.

742 Where $\mathrm{A}=$ Nuphar lutea in Haarsteegse Wiel 1977, B = Nuphar lutea in Oude Waal

743 1977, $\mathrm{C}=$ Nuphar lutea in Voorste Goorven 1988, D = Nymphaea candida in 
744 Haarsteegse Wiel 1977, E = Nymphaea alba in Oude Waal 1977, F = Nymphaea alba in

745 Voorste Goorven 1988.

746 